\title{
Pivotal role of Cu,Zn-superoxide dismutase in endothelium-dependent hyperpolarization
}

\author{
Keiko Morikawa, ${ }^{1}$ Hiroaki Shimokawa, ${ }^{1}$ Tetsuya Matoba, ${ }^{1}$ Hiroshi Kubota, ${ }^{1}$ \\ Takaaki Akaike, ${ }^{2}$ M.A. Hassan Talukder, ${ }^{1}$ Makoto Hatanaka, ${ }^{1}$ Takako Fujiki, ${ }^{1}$ \\ Hiroshi Maeda, ${ }^{2}$ Shosuke Takahashi, ${ }^{3}$ and Akira Takeshita ${ }^{1}$

\begin{abstract}
${ }^{1}$ Department of Cardiovascular Medicine, Kyushu University Graduate School of Medical Sciences, Fukuoka, Japan ${ }^{2}$ Department of Microbiology, Graduate School of Medical Sciences, Kumamoto University, Kumamoto, Japan

${ }^{3}$ Department of Anesthesiology, Kyushu University Graduate School of Medical Sciences, Fukuoka, Japan
\end{abstract}

\begin{abstract}
The endothelium plays an important role in maintaining vascular homeostasis by synthesizing and releasing several vasodilating factors, including prostacyclin, $\mathrm{NO}$, and endothelium-derived hyperpolarizing factor (EDHF). We have recently identified that endothelium-derived $\mathrm{H}_{2} \mathrm{O}_{2}$ is an EDHF in mesenteric arteries of mice and humans and in porcine coronary microvessels. However, the mechanism for the endothelial production of $\mathrm{H}_{2} \mathrm{O}_{2}$ as an EDHF remains to be elucidated. In this study, we tested our hypothesis that $\mathrm{Cu}, \mathrm{Zn}$-superoxide dismutase (Cu, $\mathrm{Zn}$-SOD) plays a pivotal role in endothelium-dependent hyperpolarization, using control and $\mathrm{Cu}, \mathrm{Zn}$-SOD ${ }^{-/}$mice. In mesenteric arteries, EDHF-mediated relaxations and hyperpolarizations were significantly reduced in $\mathrm{Cu}, \mathrm{Zn}-\mathrm{SOD}^{-/-}$mice with no inhibitory effect of catalase, while endothelium-independent relaxations and hyperpolarizations were preserved. Endothelial $\mathrm{H}_{2} \mathrm{O}_{2}$ production also was significantly reduced in $\mathrm{Cu}, \mathrm{Zn}$-SOD ${ }^{-/-}$mice. In Langendorff isolated heart, bradykinin-induced increase in coronary flow was significantly reduced in $\mathrm{C} u, \mathrm{Zn}-\mathrm{SOD}^{-/-}$mice, again with no inhibitory effect of catalase. The exogenous SOD mimetic tempol significantly improved EDHF-mediated relaxations and hyperpolarizations and coronary flow response in $\mathrm{Cu}, \mathrm{Zn}$-SOD ${ }^{-/-}$mice. These results prove the novel concept that endothelial $\mathrm{Cu}, \mathrm{Zn}$-SOD plays an important role as an "EDHF synthase" in mice, in addition to its classical role to scavenge superoxide anions.
\end{abstract}

J. Clin. Invest. 112:1871-1879 (2003). doi:10.1172/JCI200319351.

\section{Introduction}

The endothelium plays an important role in maintaining vascular homeostasis by synthesizing and releasing several vasodilators, including prostacyclin, $\mathrm{NO}$, and endothelium-derived hyperpolarizing factor (EDHF) $(1,2)$. EDHF plays an important role in modulating vascular tone, especially in microvessels (1-3). Since the first reports on the existence of $\operatorname{EDHF}(4,5)$, several candidates for EDHF have been proposed, including cytochrome $\mathrm{P} 450$ metabolites $(6,7)$, potassium ions $(8$, 9 ), and gap junctional electrical communication (10, 11). We have recently identified that endotheliumderived $\mathrm{H}_{2} \mathrm{O}_{2}$ is an EDHF in mesenteric arteries of mice

Received for publication June 30, 2003, and accepted in revised form October 21, 2003.

Address correspondence to: Hiroaki Shimokawa, Department of Cardiovascular Medicine, Kyushu University Graduate School of Medical Sciences, Fukuoka 812-8582, Japan.

Phone: 81-92-642-5360; Fax: 81-92-642-5374;

E-mail: shimo@cardiol.med.kyushu-u.ac.jp.

Conflict of interest: The authors have declared that no conflict of interest exists.

Nonstandard abbreviations used: endothelium-derived hyperpolarizing factor (EDHF); superoxide dismutase (SOD); copper,zinc-SOD (Cu,Zn-SOD); manganese SOD (MnSOD); extracellular SOD (ecSOD); prostaglandin $\mathrm{F}_{2 \alpha}\left(\mathrm{PGF}_{2 \alpha}\right)$; acetylcholine (ACh); calcium-activated potassium channels (KCa channels); $\mathrm{N}^{\omega}$-nitro-L-arginine (L-NNA);

$2^{\prime}, 7^{\prime}$-dichlorodihydrofluorescein diacetate (DCF).
(3) and humans (12) and in porcine coronary microvessels (13). Subsequently other investigators have confirmed the importance of $\mathrm{H}_{2} \mathrm{O}_{2}$ as an endogenous EDHF in coronary microvessels $(14,15)$ and piglet pial arterioles (16). However, the mechanism for the endothelial production of $\mathrm{H}_{2} \mathrm{O}_{2}$ as an endogenous EDHF remains to be elucidated. In endothelial cells, $\mathrm{H}_{2} \mathrm{O}_{2}$ is mainly produced by superoxide dismutase (SOD) from superoxide anions.

There are three isoforms of SOD that dismutate superoxide anions to $\mathrm{H}_{2} \mathrm{O}_{2}$. Copper,zinc-SOD $(\mathrm{Cu}, \mathrm{Zn}$ SOD, or SOD1) is located in the cytosol and nucleus and to a lesser extent in the mitochondria, and is expressed in almost all cell types (17). $\mathrm{Cu}, \mathrm{Zn}-\mathrm{SOD}$ is reported to dismutate superoxide anions derived from eNOS during NO synthesis (18) and thereby prolongs the half-life of NO $(19,20)$. Manganese SOD (MnSOD, or SOD2) is located in the mitochondrial matrix and is the primary SOD isoform that dismutates superoxide anions generated by the respiratory chain (21). Extracellular SOD (ecSOD, or SOD3) is secreted extracellularly and is bound to sulfated polysaccharides such as heparan sulfate on cell surfaces (21). Cu, $\mathrm{Zn}$ SOD is a major SOD in blood vessels, accounting for approximately $50-80 \%$ of total SOD activity $(22,23)$. Since we have found that endothelial production of $\mathrm{H}_{2} \mathrm{O}_{2} /$ EDHF is reduced in eNOS-knockout $\left(\mathrm{eNOS}^{-/-}\right)$ mice (3), we hypothesized that $\mathrm{H}_{2} \mathrm{O}_{2}$ is produced by 
endothelial $\mathrm{Cu}, \mathrm{Zn}-\mathrm{SOD}$ from superoxide anions (mainly derived from eNOS) and acts as an endogenous EDHF. In this study, we examined our hypothesis that endothelial $\mathrm{Cu}, \mathrm{Zn}$-SOD plays a pivotal role as an EDHF synthase using $\mathrm{Cu}, \mathrm{Zn}$-SOD knockout $\left(\mathrm{Cu}, \mathrm{Zn}-\mathrm{SOD}^{-/-}\right)$mice.

\section{Methods}

Animals and tissue preparation. Male $\mathrm{Cu}, \mathrm{Zn}-\mathrm{SOD}^{-/-}$and control mice (10-16 weeks of age) derived from breeding pairs of heterozygous $\left(\mathrm{Cu}, \mathrm{Zn}-\mathrm{SOD}^{+/-}\right)$mice (The Jackson Laboratory, Bar Harbor, Maine, USA) were used. Systolic blood pressure was measured by the tailcuff method under conscious conditions before the animals were sacrificed (3). The animals were anesthetized with intraperitoneal pentobarbital $(50 \mathrm{mg} / \mathrm{kg})$, and small mesenteric arteries, heart, and liver were excised to be used for the experiments. This study was approved by the Research Committee of the Kyushu University Graduate School of Medical Sciences.

Western blot analysis for SOD isoforms and eNOS. Western blot analysis was performed using an antibody that specifically recognizes proteins including $\mathrm{Cu}, \mathrm{Zn}-\mathrm{SOD}$, MnSOD, ecSOD, and eNOS. Mesenteric arteries were homogenized and proteins were extracted. The same amount of extracted protein $(10-20 \mu \mathrm{g}$ for each experiment) was loaded for SDS-PAGE/immunoblot analysis. The regions containing SOD isoform proteins and eNOS proteins were visualized using the ECL Plus Western Blotting Detection System (Amersham Biosciences, Buckinghamshire, United Kingdom).

$\mathrm{Cu}, \mathrm{Zn}$-SOD activity. $\mathrm{Cu}, \mathrm{Zn}-\mathrm{SOD}$ activity in the mesenteric arteries was examined using a nitroblue tetrazolium method as described previously (24). Briefly, $20 \mu \mathrm{g}$ of tissue protein was separated on a nondenaturing polyacrylamide gel. The SOD activity was visualized by initially soaking the gel in $2.43 \mathrm{mM}$ nitroblue tetrazolium for 30 minutes, followed by incubation in a solution of $0.036 \mathrm{M}$ potassium phosphate buffer containing $0.028 \mathrm{mM}$ riboflavin and $280 \mathrm{mM}$ tetramethyl ethylenediamine (24).

Glutathione peroxidase activity. Glutathione peroxidase activity of the liver was examined by the oxidation of $\mathrm{NADPH}$ in the presence of glutathione reductase, which catalyzes the reduction of oxidized glutathione formed by glutathione peroxidase (25). Liver was homogenized, proteins were extracted, and the sample protein and the reagent (containing $0.1 \mathrm{M}$ Tris- $\mathrm{HCl}$, $0.2 \mathrm{mM}$ NADPH, $0.5 \mathrm{mM}$ EDTA, $2 \mathrm{mM}$ glutathione, and 1 unit of glutathione reductase) were incubated in a total volume of $1 \mathrm{ml}$ for 2 minutes at $37^{\circ} \mathrm{C}$. Then $t$-butyl hydroperoxide $(0.07 \mathrm{mM})$ was added to the reagent well and absorbance was measured at $340 \mathrm{~nm}$ every 10 seconds for 2 minutes.

Catalase activity. Catalase activity of the liver was determined as previously described (25). Briefly, $2.25 \mathrm{ml}$ phosphate buffer $(1.0 \mathrm{M}), 9 \mathrm{ml}$ methanol $(12 \mathrm{M}), 1.8 \mathrm{ml}$ $\mathrm{H}_{2} \mathrm{O}_{2}(44 \mathrm{mM})$, and $6.75 \mathrm{ml}$ distilled water were mixed. Then $50 \mu \mathrm{l}$ of the mixed solution, $0.5 \mu \mathrm{l}$ sample protein, and $49.5 \mu \mathrm{l}$ phosphate buffer were incubated for 20 minutes, and $75 \mu \mathrm{l}$ Purpald (Sigma-Aldrich, St. Louis, Missouri, USA) (25 $\mathrm{mM}$ in $2 \mathrm{~N}$ potassium hydroxide) was added to the reagent and this was incubated for 20 minutes. Finally, $25 \mu \mathrm{l}$ of potassium periodate (65.2 $\mathrm{mM}$ ) was added and the absorbance of the purple formaldehyde adduct was measured at $550 \mathrm{~nm}$ (25).

Organ chamber experiments. Experiments were performed in $37^{\circ} \mathrm{C}$ Krebs solution bubbled with $95 \% \mathrm{O}_{2}$ and $5 \% \mathrm{CO}_{2}$. Small mesenteric arteries $(200-250 \mu \mathrm{m})$ were cut into rings and isometric tension was recorded in isolated arterial rings contracted with prostaglandin $\mathrm{F}_{2 \alpha}\left(\mathrm{PGF}_{2 \alpha}\right)(3-10 \mu \mathrm{M})$ or $\mathrm{KCl}(40-60 \mathrm{mM})(3,12)$. The extent of contraction in response to $\mathrm{PGF}_{2 \alpha}$ was adjusted to $50-70 \%$ of that induced by $60 \mathrm{mM} \mathrm{KCl}$. We examined endothelium-dependent relaxations in response to acetylcholine (ACh) as well as endothelium-independent relaxations in response to sodium nitroprusside; NS-1619, an opener of the large conductance calcium-activated potassium (KCa) channels; and exogenous $\mathrm{H}_{2} \mathrm{O}_{2}$. The contribution of vasodilator prostaglandins, $\mathrm{NO}$, and EDHF to ACh-induced endothelium-dependent relaxation was estimated by determining the inhibitory effects of indomethacin $\left(10^{-5} \mathrm{M}\right), \mathrm{N}^{\omega}$-nitro-Larginine (L-NNA, $\left.10^{-4} \mathrm{M}\right)$, and $\mathrm{KCl}(40-60 \mathrm{mM})$, respectively $(3,12)$. We have confirmed that the addition of carboxy-2-(4-carboxyphenyl)-4, 4,5,5-tetramethylimidazoline-1-oxyl 3-oxide (carboxy-PTIO, a scavenger of NO) (26) to these concentrations of indomethacin and L-NNA does not further inhibit the endotheliumdependent relaxations to $\mathrm{ACh}$, indicating that the blockade of eNOS with L-NNA may be complete (data not shown). In addition, we examined the inhibitory effect of $100 \mathrm{nM}$ charybdotoxin (an inhibitor of large and intermediate-conductance KCa channels) and 1 $\mu \mathrm{M}$ apamin (an inhibitor of small-conductance $\mathrm{KCa}$ channels). The combination of the two KCa channel blockers has been widely used to evaluate EDHF-mediated relaxations (1). Indomethacin, L-NNA, charybdotoxin, apamin, and the SOD mimetic 4-hydroxy-2,2,6,6tetramethylpiperidine-1-oxyl (tempol, $1 \mathrm{mM}$ ) (27) was applied to organ chambers 30 minutes before precontraction with $\mathrm{PGF}_{2 \alpha}$, and catalase $(6,250 \mathrm{U} / \mathrm{ml})$ was applied 1 hour before the precontraction $(3,12,13)$. When we used endothelium-denuded arteries, we removed endothelial cells mechanically $(3,12,13)$.

Electrophysiological experiments. Electrophysiological experiments were performed in isolated small mesenteric arteries. The rings of small mesenteric arteries from both strains were placed in experimental chambers perfused with $37^{\circ} \mathrm{C}$ Krebs solution containing indomethacin $\left(10^{-5} \mathrm{M}\right)$ and L-NNA $\left(10^{-4} \mathrm{M}\right)(3)$. A fine glass capillary microelectrode was stuck into the smooth muscle cell from the adventitial side (3). Changes in membrane potentials produced by ACh were continuously recorded (3). The SOD mimetic tempol $(1 \mathrm{mM})(27)$ was applied 30 minutes before membrane potential recordings, and catalase $(6,250$ $\mathrm{U} / \mathrm{ml}$ ) was applied 60 minutes before the experiment. 
Detection of ACh-induced $\mathrm{H}_{2} \mathrm{O}_{2}$ production by endothelial cells. Detection of $\mathrm{H}_{2} \mathrm{O}_{2}$ production by endothelial cells with a peroxide-sensitive fluorescent dye was performed as previously described (3). Briefly, small mesenteric arteries of control and $\mathrm{C} u, \mathrm{Zn}$-SOD $\mathrm{D}^{-/-}$mice were cut into rings and then opened longitudinally. The vascular strip was incubated with $5 \mu \mathrm{M} 2^{\prime}, 7^{\prime}$ dichlorodihydrofluorescein diacetate (DCF) for 15 minutes, then placed on a glass slide and observed using a laser confocal microscope at an excitation wavelength of $488 \mathrm{~nm}$ and an emission wavelength of 520 $\mathrm{nm}$ at $25^{\circ} \mathrm{C}$. Fluorescence images of the endothelium were obtained before and 3 minutes after application of ACh, which was achieved by dropping HEPES buffer containing $10 \mu \mathrm{M}$ ACh onto the glass slide. Relative fluorescence intensity was calculated using images obtained under basal conditions without ACh.

Langendorff isolated heart preparation. A Langendorff experiment was performed as previously described (28, 29). Briefly, hearts were quickly excised and placed in heparinized ice-cold buffer to arrest cardiac contraction. After all extracardiac tissues were removed, the aorta was carefully tied to an aortic cannula made from a 20gauge blunted needle. Hearts were perfused retrogradely at a constant pressure of $80 \mathrm{mmHg}$ with warm KrebsHenseleit buffer in standard Langendorff fashion. Once they were cannulated and the perfusion had started, the hearts were surrounded by a water-jacketed organ bath for maintenance of constant temperature. They were paced electrically at a constant rate throughout the experiment. Coronary flow was recorded with a flow meter using an ultrasonic flow probe connected in-line with the aortic perfusate. Coronary flow increase in response to bradykinin, and the effects of catalase $(1,250 \mathrm{U} / \mathrm{ml})$ and tempol $(1 \mathrm{mM})$ were examined.

Drugs and solutions. The ionic composition $(\mathrm{mM})$ of Krebs solution was $\mathrm{Na}^{+} 144, \mathrm{~K}^{+} 5.9, \mathrm{Mg}^{2+} 1.2, \mathrm{Ca}^{2+} 2.5$, $\mathrm{H}_{2} \mathrm{PO}_{4}^{-}$1.2, $\mathrm{HCO}_{3}{ }^{-} 24, \mathrm{Cl}^{-} 129.7$, glucose 5.5 ; that of HEPES buffer was $\mathrm{Na}^{+} 143, \mathrm{~K}^{+} 5.9, \mathrm{Mg}^{2+} 1.2, \mathrm{Ca}^{2+} 1.6$, $\mathrm{H}_{2} \mathrm{PO}_{4}^{-}$1.2, $\mathrm{Cl}^{-} 150.9$, glucose 11, HEPES 5; and that of Krebs-Henseleit buffer was $\mathrm{Na}^{+} 144, \mathrm{~K}^{+} 5.9, \mathrm{Mg}^{2+}$ $1.2, \mathrm{Ca}^{2+} 2.5, \mathrm{H}_{2} \mathrm{PO}_{4}^{-} 1.2, \mathrm{HCO}_{3}{ }^{-} 25, \mathrm{Cl}^{-} 127.7$, glucose 11, EDTA 0.5 , and pyruvate 2.0. Antibodies to $\mathrm{Cu}, \mathrm{Zn}$ -
SOD and MnSOD were obtained from Stressgen Biotechnologies Corp. (Victoria, British Columbia, Canada) and eNOS antibody was obtained from Transduction Laboratories (Franklin Lakes, New Jersey, USA). Levcromakalim was obtained from Tocris Cookson Inc. (Ellisville, Missouri, USA) and sodium nitroprusside was obtained from Maruishi Seiyaku Co. (Osaka, Japan). DCF was obtained from Molecular Probes Inc. (Eugene, Oregon, USA). All other agents were obtained from Sigma-Aldrich.

Statistics. Results are expressed as mean \pm SEM. Doseresponse curves were analyzed by two-way ANOVA followed by the Scheffé post-hoc test for multiple comparisons. Other values were analyzed by paired and unpaired Student's $t$ test or one-way ANOVA. $P<0.05$ was considered to be statistically significant.

\section{Results}

Characterization of $\mathrm{Cu}, \mathrm{Zn}-\mathrm{SOD}^{-/-}$mice. There was no significant difference in systolic blood pressure $(\mathrm{mmHg})$ between the $\mathrm{Cu}, \mathrm{Zn}$-SOD $D^{-/-}$mice $(117 \pm 3)$ and the control mice $(120 \pm 4)(n=17$ each). Western blot analysis showed that expression of $\mathrm{Cu}, \mathrm{Zn}-\mathrm{SOD}$ was absent in mesenteric arteries from the $\mathrm{Cu}, \mathrm{Zn}-\mathrm{SOD}^{-/-}$mice, whereas the expression of MnSOD or ecSOD was unchanged (Figure 1a). The $\mathrm{Cu}, \mathrm{Zn}-\mathrm{SOD}$ activity in mesenteric arteries, which was examined by a nitroblue tetrazolium method (24), was totally absent in the $\mathrm{Cu}, \mathrm{Zn}-\mathrm{SOD}^{-/-}$mice (Figure 1b). By contrast, the activities of glutathione peroxidase and catalase in the liver, both of which dismutate $\mathrm{H}_{2} \mathrm{O}_{2}$, were unchanged in the knockout mice (Figure $1, \mathrm{c}$ and $\mathrm{d}$, respectively). Western blot analysis for eNOS showed that the extent of eNOS expression was comparable between the two strains (Figure 1e).

Endothelium-dependent relaxations. In mesenteric arteries of control mice, endothelium-dependent relaxations in response to ACh were resistant to indomethacin $\left(10^{-5}\right.$ $\mathrm{M})$ or L-NNA $\left(10^{-4} \mathrm{M}\right)$ but were significantly inhibited by $\mathrm{KCl}(40-60 \mathrm{mM})$ (Figure 2a). In mesenteric arteries of $\mathrm{Cu}, \mathrm{Zn}-\mathrm{SOD}^{-/-}$mice, endothelium-dependent relaxations in response to ACh were slightly attenuated compared with those of control mice, and L-NNA markedly inhibited the relaxations (Figure $2 b$ ). Figure $2 c$ shows a

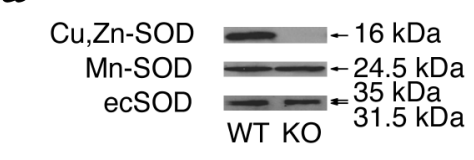

b $_{\text {Cu,Zn-SOD } \rightarrow \text { WT KO }}$
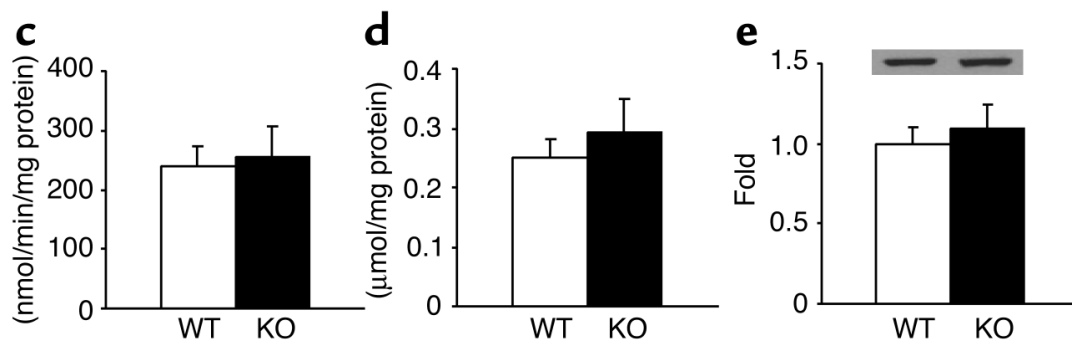

\section{Figure 1}

Characterization of $\mathrm{Cu}, \mathrm{Zn}$-SOD ${ }^{-1-}$ mice. (a) Western blot analysis for SOD isoforms in mesenteric arteries from control (WT) and Cu,Zn$S O D^{-/-}(\mathrm{KO})$ mice. Cu,Zn-SOD expression was absent in the $\mathrm{Cu}, \mathrm{Zn}-\mathrm{SO} D^{-/-}$mice, whereas the expression of MnSOD and ecSOD was unaltered. (b) $\mathrm{Cu}, \mathrm{Zn}-\mathrm{SOD}$ activity of mesenteric arteries from the two strains. $\mathrm{Cu}, \mathrm{Zn}-\mathrm{SOD}$ activity was absent in the $\mathrm{Cu}, \mathrm{Zn}$-SOD-/- mice. Comparable activities of glutathione peroxidase (c) and catalase $(\mathbf{d})$ of the liver in the two strains $(n=5$ each). (e) Western blot analysis for eNOS expression in mesenteric arteries ( $n=5$ each). eNOS protein expression was comparable between the two strains. 
the relative contributions of prostacyclin, $\mathrm{NO}$, and EDHF to the endothelium-dependent relaxations of mesenteric arteries from both strains when using $\mathrm{KCl}$ as an inhibitor of EDHF-mediated responses. In mesenteric arteries, EDHF-mediated relaxations were significantly reduced, while NO-mediated relaxations were significantly increased in $\mathrm{Cu}, \mathrm{Zn}$-SOD ${ }^{-/-}$mice compared with control mice. The combination of charybdotoxin and apamin also significantly inhibited EDHF-mediated relaxations in both strains (Figure 2, $\mathrm{d}$ and e). The EDHF-mediated relaxations, as evaluated by the inhibitory effect of the combination, were also significantly reduced in $\mathrm{Cu}, \mathrm{Zn}-\mathrm{SOD}^{-/-}$mice (Figure 2f).

Endothelium-independent relaxations. Endotheliumindependent relaxations in response to sodium nitroprusside (Figure 3a) and to NS-1619 (Figure 3b) were comparable between the two strains. Furthermore, relaxations of endothelium-denuded mesenteric arteries in response to exogenous $\mathrm{H}_{2} \mathrm{O}_{2}$ were comparable between the two strains (Figure 3c).

Endothelium-dependent and-independent hyperpolarizations. Electrophysiological recordings of membrane potentials with the microelectrode technique in mesen- teric arteries demonstrated that endothelium-dependent hyperpolarizations induced by $\mathrm{ACh}\left(10^{-5} \mathrm{M}\right)$ were significantly reduced in the $\mathrm{Cu}, \mathrm{Zn}-\mathrm{SOD}^{-/-}$mice compared with control mice (Figure 4a). By contrast, endothelium-independent hyperpolarizations induced by levcromakalim were comparable between the two strains (Figure 4b).

Inhibitory effect of catalase on EDHF-mediated responses. In the presence of indomethacin $\left(10^{-5} \mathrm{M}\right)$ and L-NNA $\left(10^{-4} \mathrm{M}\right)$, catalase significantly inhibited EDHF-mediated relaxations of mesenteric arteries from control mice (Figure 5a). By contrast, catalase had no inhibitory effect on the EDHF-mediated relaxations of mesenteric arteries from $\mathrm{Cu}, \mathrm{Zn}-\mathrm{SOD}^{-/-}$mice (Figure $5 \mathrm{~b}$ ). Catalase significantly inhibited the hyperpolarization response in control mice (Figure 5c) but not in $\mathrm{Cu}, \mathrm{Zn}$ $S O D^{-/-}$mice (Figure $5 \mathrm{~d}$ ).

ACh-induced $\mathrm{H}_{2} \mathrm{O}_{2}$ production by endothelial cells. In the control mice, ACh significantly increased the fluorescence intensity in endothelial cells (Figure 6, a and b), while in the $\mathrm{Cu}, \mathrm{Zn}-\mathrm{SOD}^{-/-}$mice, ACh-induced fluorescence intensity was significantly reduced compared with the control mice (Figure 6c). Figure 6d a

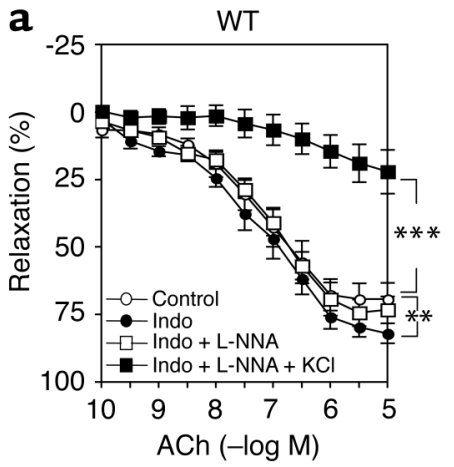

d

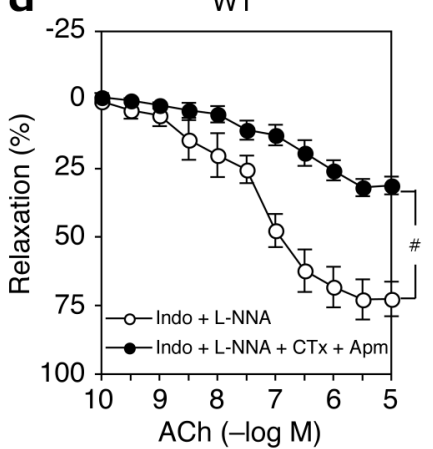

b

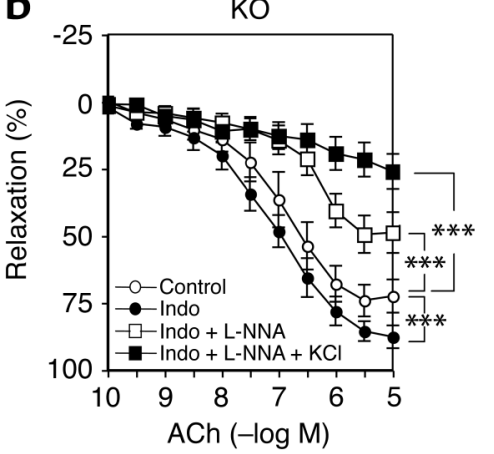

e

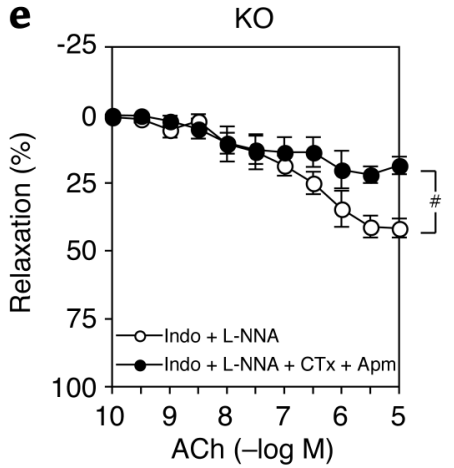

C
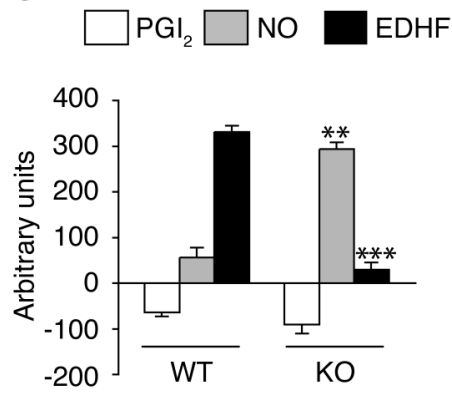

f

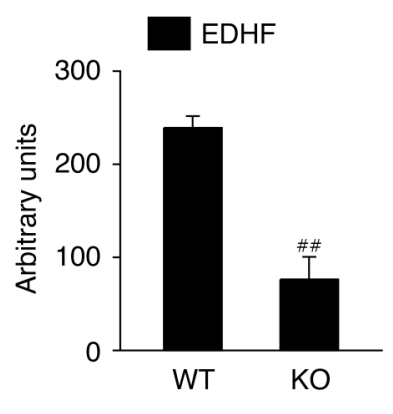

Figure 2

Reduced EDHF-mediated relaxations in $\mathrm{Cu}, \mathrm{Zn}$-SOD ${ }^{-/-}$mice. Endothelium-dependent relaxations of mesenteric arteries from control WT mice (a) and from Cu,Zn-SOD-/- mice (b) ( $n=7$ each) are shown. Indo, indomethacin (10-5 M); L-NNA, 10-4 M; KCl, 40-60 mM. In mesenteric arteries of control mice (a), endothelium-dependent relaxations were resistant to indomethacin or L-NNA, whereas in those of $\mathrm{Cu}, \mathrm{Zn}$ $S O D^{-1-}$ mice (b), indomethacin and L-NNA markedly inhibited the relaxations. ${ }^{*} P<0.01,{ }^{*} * P<0.0001$. (c) Relative contribution of prostacyclin $\left(\mathrm{PGI}_{2}\right), \mathrm{NO}$, and $\mathrm{EDHF}$ to the endothelium-dependent relaxations of mesenteric arteries in response to ACh. In mesenteric arteries from $\mathrm{Cu}, \mathrm{Zn}-\mathrm{SOD}^{-/-}$mice, EDHF-mediated relaxations were significantly attenuated and NO-mediated relaxations were significantly enhanced. ${ }^{*} P<0.01,{ }^{*} * 0<0.0001$ vs. WT. (d and $\mathbf{e}$ ) Inhibitory effect of the combination of charybdotoxin (CTx) and apamin (Apm) on EDHF-mediated relaxations. The combination significantly inhibited EDHF-mediated relaxations in both strains. ${ }^{\#} P \leq 0.0001$. (f) Relative contribution of EDHF to the endothelium-dependent relaxations of mesenteric arteries as evaluated by the inhibitory effects of charybdotoxin and apamin. EDHF-mediated relaxations were also significantly reduced in $\mathrm{Cu}, \mathrm{Zn}-\mathrm{SO} D^{-/-}$mice. ${ }^{\# \#} P \leq 0.01$. 


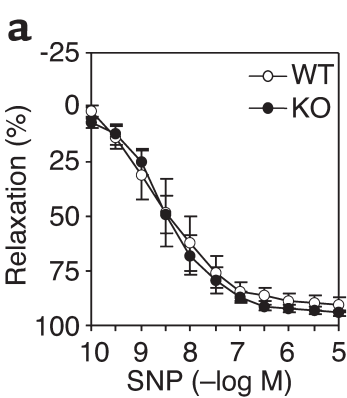

b
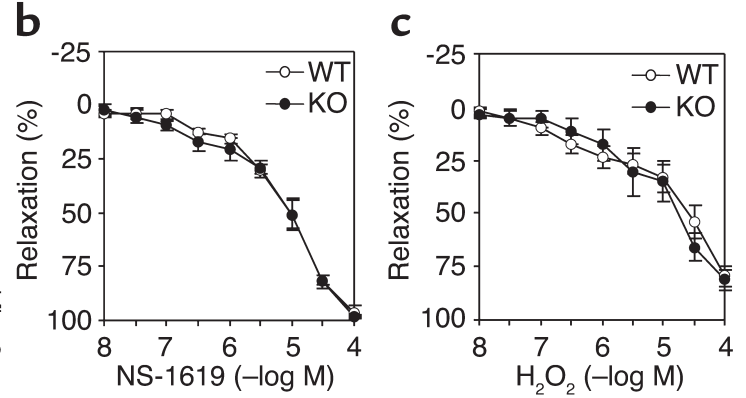

Figure 3

Preserved vascular smooth muscle cell responses in $\mathrm{Cu}, \mathrm{Zn}$-SOD ${ }^{-/-}$mice. (a) Endothelium-independent relaxations in response to sodium nitroprusside (SNP) of mesenteric arteries from control mice and $\mathrm{Cu}, \mathrm{Zn}-\mathrm{SO} \mathrm{D}^{-/-}$mice $(n=6-8)$. (b) Endothelium-independent relaxations in response to NS-1619 of mesenteric arteries from control mice and Cu,Zn-SOD $/$ - mice $(n=6-8)$. Those endothelium-independent relaxations were comparable between the two strains. (c) Exogenous $\mathrm{H}_{2} \mathrm{O}_{2}$-induced relaxations of mesenteric arteries without endothelium ( $n=6$ each). $\mathrm{H}_{2} \mathrm{O}_{2}$ caused a comparable extent of endothelium-independent relaxations in the two strains.

summarizes the relative fluorescence intensity in response to $\mathrm{ACh}$ in both strains.

Coronary flow response in isolated beart. In the presence of indomethacin $\left(10^{-5} \mathrm{M}\right)$ and L-NNA $\left(10^{-4} \mathrm{M}\right)$, bradykinin-induced increase in coronary flow was $201 \% \pm 9 \%$ of baseline in the control mice, whereas in the $\mathrm{Cu}, \mathrm{Zn}$-SOD ${ }^{-/-}$mice, the response was significantly reduced at $151 \% \pm 7 \%$ (Figure $7 \mathrm{a}$ ). Catalase significantly inhibited the coronary flow response in the control mice $(153 \% \pm 7 \%)$ but not in the $\mathrm{Cu}, \mathrm{Zn}$-SOD ${ }^{-/-}$ mice (Figure 7a). Thus, the inhibitory effect of catalase on the coronary flow response was markedly reduced in the $\mathrm{Cu}, \mathrm{Zn}$-SOD $\mathrm{S}^{-/-}$mice compared with the control mice (Figure $7 \mathrm{~b}$ ).

Effect of SOD mimetic supplementation on EDHF-mediated relaxations in $\mathrm{Cu}, \mathrm{Zn}$-SOD ${ }^{-/}$mice. Since SOD is a large molecule that penetrates the endothelium with difficulty, we used a cell-permeable SOD mimetic, tempol (27). In the presence of indomethacin $\left(10^{-5} \mathrm{M}\right)$ and L-NNA $\left(10^{-4} \mathrm{M}\right)$, tempol did not significantly improve EDHFmediated relaxations of mesenteric arteries from control mice, and the relaxations were again significantly inhibited by catalase (Figure 8a). By contrast, in mesenteric arteries from $\mathrm{Cu}, \mathrm{Zn}-\mathrm{SOD}^{-/-}$mice, tempol significantly improved the EDHF-mediated relaxations, and the enhancing effect of tempol was abolished by catalase (Figure $8 \mathrm{~b}$ ). Membrane potential recordings demonstrated that in control mice, tempol did not enhance endothelium-dependent hyperpolarizations, whereas in $\mathrm{Cu}, \mathrm{Zn}$-SOD ${ }^{-/-}$mice, it significantly enhanced the responses (Figure 8c). Importantly, this enhancing effect of tempol was totally abolished by catalase. In isolated heart studies, tempol did not enhance the bradykinin-induced increase in coronary flow in the control mice, but significantly improved the response in the $\mathrm{Cu}, \mathrm{Zn}$-SOD ${ }^{-/-}$mice (Figure $8 \mathrm{~d}$ ). In a separate experiment, the enhancing effect of tempol was abolished by catalase (control, $144 \% \pm 8 \%$ vs. tempol plus catalase, $147 \% \pm 9 \%, n=3)$.

\section{Discussion}

The novel finding of this study is that $\mathrm{Cu}, \mathrm{Zn}-\mathrm{SOD}$ plays a pivotal role in EDHF synthesis in both the mesenteric and the coronary microvessels in mice, further supporting our hypothesis that $\mathrm{H}_{2} \mathrm{O}_{2}$ is an EDHF. Although the role of $\mathrm{Cu}, \mathrm{Zn}-\mathrm{SOD}$ has been emphasized only for its effect of scavenging superoxide anions $(19,20)$, its biological role in maintaining vascular homeostasis remains to be fully elucidated. The present study demonstrates a novel role of $\mathrm{Cu}, \mathrm{Zn}-\mathrm{SOD}$ as an "EDHF synthase" in maintaining vascular homeostasis.

Characterization of $\mathrm{Cu}, \mathrm{Zn}$-SOD $\mathrm{S}^{-/-}$ mice. In $\mathrm{Cu}, \mathrm{Zn}-\mathrm{SOD}^{-/-}$mice, the expression of $\mathrm{Cu}, \mathrm{Zn}-\mathrm{SOD}$ protein was absent, while there was no upregulation of the other two SODs (MnSOD and ecSOD). Furthermore, the activities of glutathione peroxidase and catalase were comparable between the control and the $\mathrm{Cu}, \mathrm{Zn}-\mathrm{SOD}^{-/-}$mice, suggesting that these endogenous $\mathrm{H}_{2} \mathrm{O}_{2}$-scavenging enzymes are not involved in the reduced EDHF responses in $\mathrm{Cu}, \mathrm{Zn}-\mathrm{SOD}^{-/-}$mice. Regarding the other two isoforms of SOD, a role for $\mathrm{MnSOD}$ in synthesizing $\mathrm{EDHF} / \mathrm{H}_{2} \mathrm{O}_{2}$ is less likely because MnSOD is located in mitochondria (21) and thus does not seem to be involved in EDHF synthesis. We have also ruled out the possible role of ecSOD, because EDHF-mediated responses were not altered by heparin (unpublished observations).

Reduced EDHF-mediated responses in $\mathrm{Cu}, \mathrm{Zn}-\mathrm{SOD}^{-/-}$mice. Upregulated NO compensates the reduced contribution of EDHF to endothelium-dependent relaxations in $\mathrm{Cu}, \mathrm{Zn}$-SOD ${ }^{-/-}$mice, confirming the importance of endothelial $\mathrm{Cu}, \mathrm{Zn}-\mathrm{SOD}$ as an EDHF synthase. EDHFmediated relaxations were predominant in small
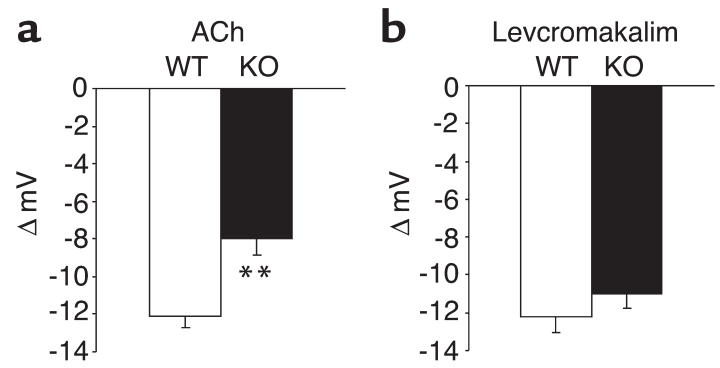

\section{Figure 4}

Endothelium-dependent and -independent hyperpolarizations of mesenteric arteries. (a) Endothelium-dependent hyperpolarizations of mesenteric arteries in response to ACh $\left(10^{-5} \mathrm{M}\right)$ were significantly attenuated in the $\mathrm{Cu}, \mathrm{Zn}-\mathrm{SO} D^{-/-}$mice $(n=4-5){ }^{* *} P<0.01 \mathrm{vs}$. WT. (b) Endothelium-independent hyperpolarizations of mesenteric arteries in response to levcromakalim $\left(10^{-5} \mathrm{M}\right)$ were comparable between the two strains $(n=4-5)$. 


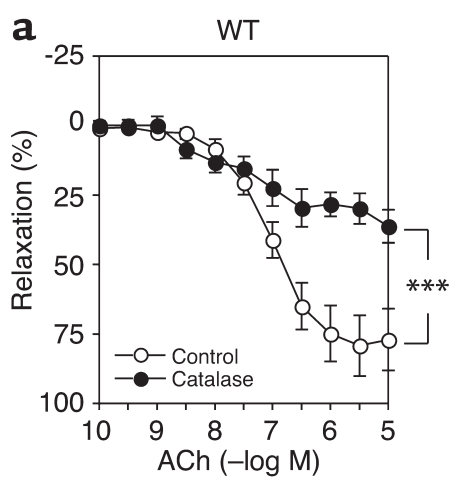

C

WT

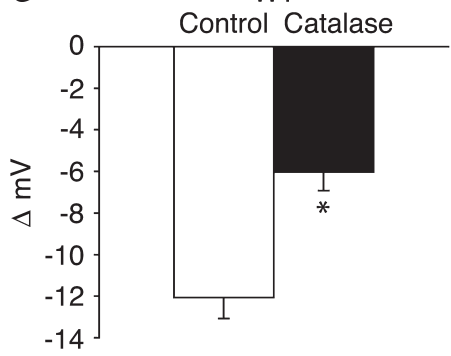

b

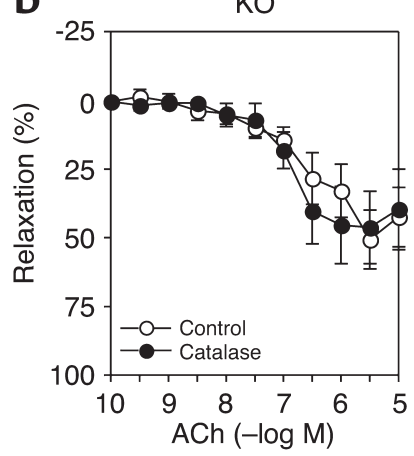

d

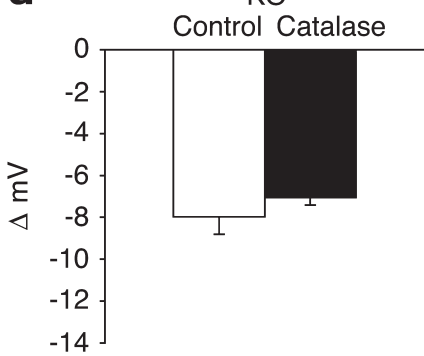

\section{Figure 5}

Inhibitory effect of catalase on EDHF-mediated relaxations and hyperpolarizations of mesenteric arteries. (a) In mesenteric arteries from control mice, catalase $(6,250 \mathrm{U} / \mathrm{ml})$ in the presence of indomethacin and L-NNA significantly inhibited EDHF-mediated relaxations ( $n=4$ each). ${ }^{* *} P<0.0001$. (b) In mesenteric arteries from $\mathrm{Cu}, \mathrm{Zn}-\mathrm{SOD}^{-/-}$mice, catalase $(6,250 \mathrm{U} / \mathrm{ml})$ had no inhibitory effect on the remaining EDHF-mediated relaxations ( $n=4$ each). (c) Catalase significantly inhibited endothelium-dependent hyperpolarizations in response to $\mathrm{ACh}\left(10^{-5} \mathrm{M}\right)$ of mesenteric arteries from control mice $(n=3)$. ${ }^{*} P \leq 0.05$. (d) Catalase had no effect on endothelium-dependent hyperpolarization of mesenteric arteries from $\mathrm{Cu}, \mathrm{Zn}-\mathrm{SOO} D^{-/-}$mice $(n=3)$. mesenteric arteries, a finding consistent with our previous studies $(2,3,30)$. EDHF-mediated relaxations, as evaluated by the combination of charybdotoxin and apamin, also were reduced in $\mathrm{Cu}, \mathrm{Zn}-\mathrm{SOD}^{-/-}$mice, further confirming the reduced EDHF response in those mice. Both the expression and the activity of $\mathrm{Cu}, \mathrm{Zn}$ SOD are enhanced by fluid shear stress in endothelial cells but not in smooth muscle cells in the human aorta (31). This finding is consistent with our present study because shear stress stimulates the synthesis of EDHF by the endothelium (32).

In the carotid artery of $\mathrm{Cu}, \mathrm{Zn}-\mathrm{SOD}^{-/-}$mice, NO-mediated relaxations were attenuated and contractile responses of vascular smooth muscle to serotonin and phenylephrine were enhanced (23). In the present study, however, NO-mediated relaxations were enhanced to partially compensate for the endotheliumdependent relaxations in mesenteric arteries. It is unlikely that upregulated eNOS is involved in this compensation because eNOS expression was unaltered in $\mathrm{Cu}, \mathrm{Zn}-\mathrm{SOD}^{-/-}$mice. Although the mechanism for the upregulation of $\mathrm{NO}$-mediated responses remains to be elucidated, this could explain, at least in part, the absence of hypertension in those mice.

\section{Figure 6}

ACh-induced production of $\mathrm{H}_{2} \mathrm{O}_{2}$ by the endothelium. $\mathrm{H}_{2} \mathrm{O}_{2}$ production by the endothelium was detected using confocal microscopy with DCF. (a) Basal fluorescence intensity. (b) Application of ACh significantly increased the fluorescence intensity in endothelial cells in a control mouse. (c) ACh-induced increase in fluorescence intensity was significantly reduced in $\mathrm{Cu}, \mathrm{Zn}-\mathrm{SOD}^{-/-}$mice. (d) Summary of ACh-induced increase in fluorescence intensity in endothelial cells. ACh significantly increased the fluorescence intensity in control mice but not in $\mathrm{Cu}, \mathrm{Zn}-\mathrm{SOD}^{-/-}$mice $\left(n=5\right.$ each). ${ }^{\#} P \leq 0.0001$.

Several abnormalities have been reported in the cardiovascular system of $\mathrm{Cu}, \mathrm{Zn}-\mathrm{SOD}^{-/-}$mice. In those mice, myocardial ischemia-reperfusion injury was enhanced (33), as was cerebral injury after transient ischemia (34). It remains to be elucidated to what extent $\mathrm{Cu}, \mathrm{Zn}-\mathrm{SOD}$ contributes to those abnormalities as an EDHF synthase in $\mathrm{Cu}, \mathrm{Zn}$-SOD ${ }^{-/-}$mice.

$\mathrm{H}_{2} \mathrm{O}_{2}$ plays an important role in many blood vessels under physiological conditions as an endogenous relaxing and hyperpolarizing factor. Indeed, $\mathrm{H}_{2} \mathrm{O}_{2}$ causes relaxations and hyperpolarizations $(3,12,13,16,35$, 36). We were recently able to demonstrate the endothelial production of $\mathrm{H}_{2} \mathrm{O}_{2}$ as an endogenous EDHF in

a

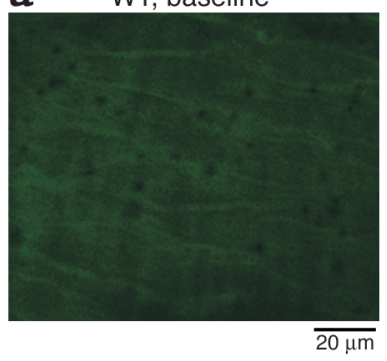

c $\mathrm{KO}, \mathrm{ACh}$

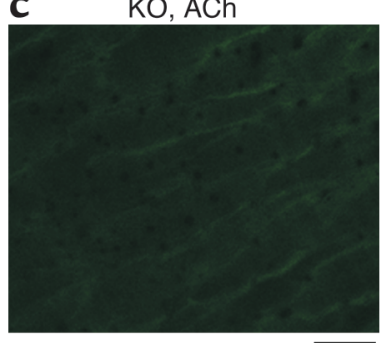

b

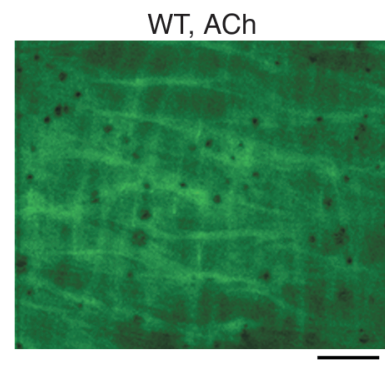

d

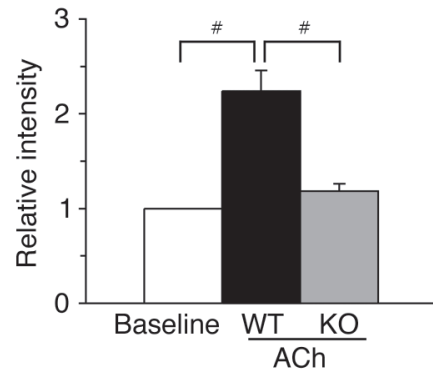



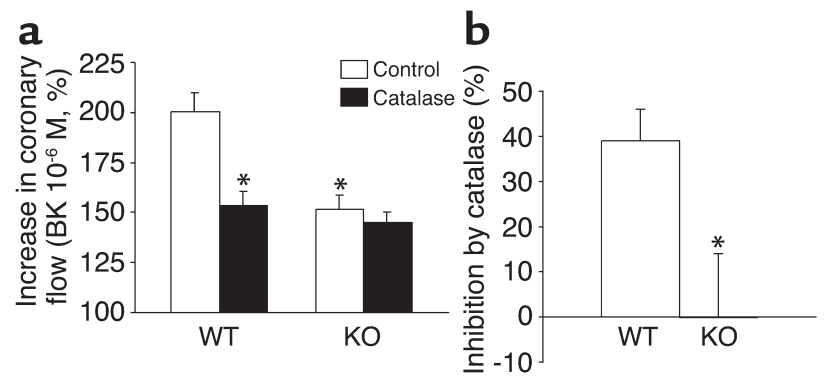

porcine coronary microvessels by an electron spin resonance method (13). It has recently been reported that endothelial production of superoxide anions from eNOS and the subsequent synthesis of $\mathrm{H}_{2} \mathrm{O}_{2}$ are increased in the aorta of deoxycorticosterone acetatesalt hypertensive rats and that this eNOS-derived $\mathrm{H}_{2} \mathrm{O}_{2}$ is involved in endothelium-dependent relaxations in response to calcium ionophore A23187 (37). The increase in endothelial $\mathrm{H}_{2} \mathrm{O}_{2}$ production was due to oxidation of tetrahydrobiopterin that resulted in eNOS uncoupling (37). However, endothelial production of superoxide anions from eNOS is noted even under physiological conditions without deficiencies of tetrahydrobiopterin (18). Thus, we consider that endothelial production of superoxide anions by eNOS

\section{Figure 7}

Reduced coronary flow increase in $\mathrm{Cu}, \mathrm{Zn}-\mathrm{SOD}^{-/-}$mice. (a) Coronary flow increase in response to bradykinin $(B K)\left(10^{-6} \mathrm{M}\right)$ in isolated heart was significantly attenuated in the $\mathrm{Cu}, \mathrm{Zn}-\mathrm{SO}^{-/-}$mice compared with the control mice ( $n=6$ each). Catalase significantly inhibited the coronary flow increase in control mice, but not in $\mathrm{Cu}, \mathrm{Zn}$ $S O D^{-/-}$mice. ${ }^{*} P<0.05$ vs. WT control. (b) The inhibitory effect of catalase on bradykinin-induced increase in coronary flow was absent in $\mathrm{Cu}, \mathrm{Zn}-\mathrm{SOD}^{-/-}$mice. ${ }^{*} P<0.05$ vs. WT.

and subsequent synthesis of $\mathrm{H}_{2} \mathrm{O}_{2}$ by $\mathrm{Cu}, \mathrm{Zn}$-SOD are physiological phenomena and play a pivotal role in maintaining vascular homeostasis.

Preserved vascular smooth muscle responses in $\mathrm{Cu}, \mathrm{Zn}$-SOD ${ }^{-/-}$ mice. Endothelium-independent relaxations in response to sodium nitroprusside, NS-1619, and exogenous $\mathrm{H}_{2} \mathrm{O}_{2}$ were comparable between the two strains and endothelium-independent hyperpolarizations induced by levcromakalim also were unchanged in $\mathrm{Cu}, \mathrm{Zn}-\mathrm{SOD}^{-/-}$mice, suggesting that relaxation properties of vascular smooth muscle cells were preserved in those mice.

Decreased inbibitory effect of catalase on EDHF-mediated relaxations and hyperpolarizations in $\mathrm{Cu}, \mathrm{Zn}$-SOD ${ }^{-1-}$ mice. In mesenteric arteries from control mice, pretreatment with catalase significantly inhibited EDHF-mediated a
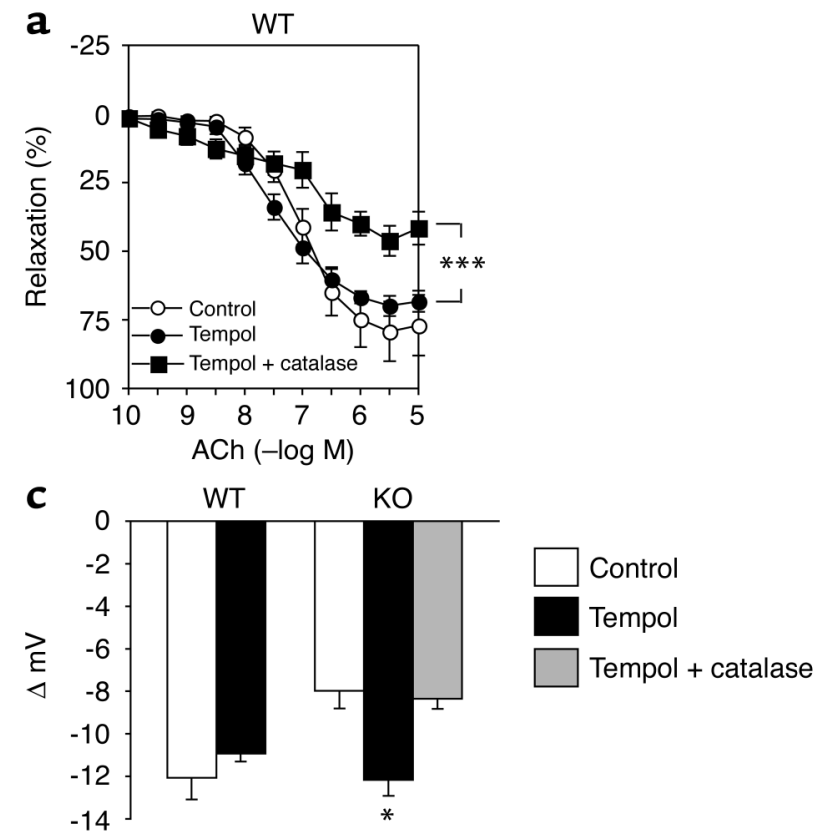
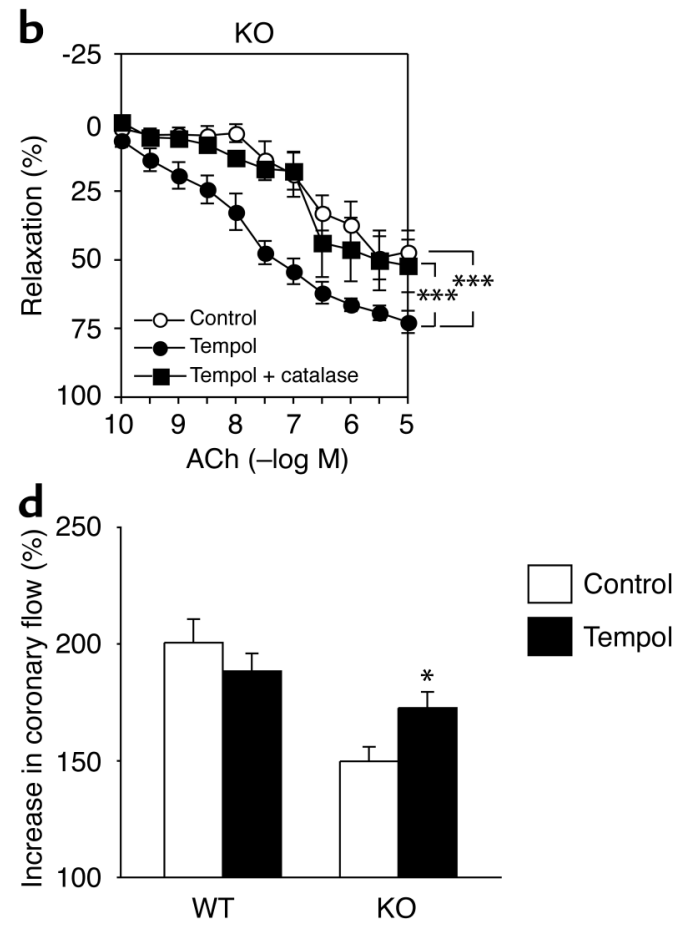

Figure 8

Effect of supplementation of SOD mimetic on EDHF-mediated relaxations in $\mathrm{Cu}, \mathrm{Zn}$-SOD-/- mice. (a) In the presence of indomethacin and L-NNA, the SOD mimetic tempol $(1 \mathrm{mM})$ did not improve the EDHF-mediated relaxations of mesenteric arteries from control mice, which were significantly inhibited by catalase $(6,250 \mathrm{U} / \mathrm{ml})\left(n=6\right.$ each). (b) In mesenteric arteries from $\mathrm{Cu}, \mathrm{Zn}-\mathrm{SO} D^{-/-}$mice, tempol ( $\left.1 \mathrm{mM}\right)$ in the presence of indomethacin and L-NNA significantly enhanced EDHF-mediated relaxations, an effect that was abolished by catalase $(6,250$ $\mathrm{U} / \mathrm{ml})\left(n=5\right.$ each). ${ }^{*}{ }^{*} P<0.0001$. (c) Tempol did not improve hyperpolarizations in control mice but did so in $\mathrm{Cu}, \mathrm{Zn}-\mathrm{SO} D^{-/-}$mice, and that effect was abolished by simultaneous administration of catalase $(6,250 \mathrm{U} / \mathrm{ml})$. (d) In isolated heart, tempol did not improve the coronary flow responses in control mice, but did so in $\mathrm{Cu}, \mathrm{Zn}-\mathrm{SOD}^{-/-}$mice. ${ }^{*} P \leq 0.05$. 
relaxations, suggesting that those relaxations were mediated by $\mathrm{H}_{2} \mathrm{O}_{2}$ in control mice, a finding consistent with our previous studies (3). By contrast, in mesenteric arteries from $\mathrm{Cu}, \mathrm{Zn}-\mathrm{SOD}^{-/-}$mice, the inhibitory effect of catalase was absent, suggesting that the contribution of $\mathrm{H}_{2} \mathrm{O}_{2}$ to EDHF-mediated relaxations is markedly reduced in those mice. Catalase also significantly inhibited endothelium-dependent hyperpolarization in control mice, while it had no inhibitory effect in $\mathrm{Cu}, \mathrm{Zn}-\mathrm{SOD}^{-/-}$mice. These results further support our hypothesis that endothelial $\mathrm{Cu}, \mathrm{Zn}-\mathrm{SOD}$ plays a pivotal role in the production of $\mathrm{H}_{2} \mathrm{O}_{2} / E D H F$.

Decreased formation of ACh-induced $\mathrm{H}_{2} \mathrm{O}_{2}$ in $\mathrm{Cu}, \mathrm{Zn}$ $\mathrm{SOD}^{-/-}$mice. Microscopy of DCF-stained vascular endothelium demonstrated that ACh-induced fluorescence intensity was significantly reduced in $\mathrm{Cu}, \mathrm{Zn}$ $\mathrm{SOD}^{-/-}$mice compared with control mice. This suggests that ACh-induced endothelial production of $\mathrm{H}_{2} \mathrm{O}_{2}$ was significantly decreased in $\mathrm{Cu}, \mathrm{Zn}-\mathrm{SOD}^{-/-}$mice, further confirming the importance of $\mathrm{Cu}, \mathrm{Zn}-\mathrm{SOD}$ in endothelial synthesis of $\mathrm{H}_{2} \mathrm{O}_{2} /$ EDHF.

Reduced coronary flow response in $\mathrm{Cu}, \mathrm{Zn}$-SOD ${ }^{-/-}$mice. In $\mathrm{Cu}, \mathrm{Zn}-\mathrm{SOD}^{-/-}$mice, EDHF-mediated increase in coronary flow was also significantly reduced, and the remaining coronary flow was no longer sensitive to catalase. These results indicate that catalase-sensitive, $\mathrm{H}_{2} \mathrm{O}_{2}$-mediated relaxations of coronary microvessels were almost absent in $\mathrm{Cu}, \mathrm{Zn}-\mathrm{SOD}^{-/-}$mice, confirming the importance of $\mathrm{Cu}, \mathrm{Zn}-\mathrm{SOD}$ in the coronary circulation.

Improvement of EDHF-mediated responses by an SOD mimetic in $\mathrm{Cu}, \mathrm{Zn}-\mathrm{SOD}^{-/-}$mice. Since SOD is a large molecule and penetrates the endothelium only with difficulty, we used the cell-permeable SOD mimetic tempol. Tempol is a stable nitroxide and has been reported to act as an SOD mimetic and to dismutate superoxide into $\mathrm{H}_{2} \mathrm{O}_{2}(27,38)$. In the present study, tempol significantly improved the EDHF-mediated relaxations and hyperpolarizations of mesenteric arteries and also significantly improved the coronary flow response to bradykinin in $\mathrm{Cu}, \mathrm{Zn}-\mathrm{SOD}^{-/-}$mice, further confirming the pivotal role of the enzyme in endothelium-dependent hyperpolarization. Catalase completely inhibited this effect of tempol, indicating that the effect of tempol was mediated by $\mathrm{H}_{2} \mathrm{O}_{2}$. By contrast, tempol had no augmenting effect on the EDHF-mediated relaxations and hyperpolarizations of mesenteric arteries and coronary flow responses in control mice, suggesting that a sufficient amount of SOD is present in those mice.

Limitations of the study. Several limitations of the present study should be mentioned. First, we did not demonstrate the endothelial source of superoxide anions that are dismutated into $\mathrm{H}_{2} \mathrm{O}_{2}$. Since EDHFmediated relaxations are significantly attenuated in eNOS ${ }^{-1-}$ mice, it is possible that eNOS is one of the important sources of superoxide anions (3). Other possible sources of superoxide anions and the details of the interaction between eNOS and other enzymes remain to be examined in future studies. Second, while we were able to demonstrate the reduced $\mathrm{H}_{2} \mathrm{O}_{2}$ pro- duction by the endothelium in $\mathrm{Cu}, \mathrm{Zn}-\mathrm{SOD}^{-/-}$mice using confocal microscopy with DCF, we were unable to quantitatively measure endothelial $\mathrm{H}_{2} \mathrm{O}_{2}$ production because a sufficient amount of mesenteric microvessels was not available in mice. However, we have recently demonstrated with an electron spin resonance method that endothelial cells produce $\mathrm{H}_{2} \mathrm{O}_{2}$, at least in micromolar quantities, in porcine coronary microvessels under physiological conditions (13). Third, the mechanisms for the compensatory role of $\mathrm{NO}$ in $\mathrm{Cu}, \mathrm{Zn}-\mathrm{SOD}^{-/-}$mice remain to be elucidated. Fourth, we did not elucidate the mechanisms for the remaining EDHF-mediated responses in $\mathrm{Cu}, \mathrm{Zn}-\mathrm{SOD}^{-/-}$mice. Fifth, although we demonstrated the importance of $\mathrm{Cu}, \mathrm{Zn}$-SOD as an EDHF synthase in mesenteric arteries in vitro and in the coronary circulation ex vivo, the importance of the enzyme in EDHF-mediated responses in vivo remains to be examined.

Clinical implications. EDHF plays an important role in human arteries, especially in microvessels $(39,40)$. We have recently observed that SOD mimetics also improve EDHF-mediated relaxations and hyperpolarizations in human mesenteric arteries (unpublished observations). It has been reported that abnormality in $\mathrm{Cu}, \mathrm{Zn}-\mathrm{SOD}$ processing and mutation of genes encoding $\mathrm{Cu}, \mathrm{Zn}-\mathrm{SOD}$ is involved in the pathogenesis of several diseases, including diabetes mellitus, hypertension, amyotrophic lateral sclerosis, Down syndrome, and malignant breast diseases (41-44). It has also been reported that $\mathrm{Cu}, \mathrm{Zn}$-SOD is important for ovary function (45) and hearing function (46). EDHF-mediated relaxations are impaired in several disease states, including hypercholesterolemia and aging (39), which may promote the progression of vascular disease, especially at microvascular levels. It remains to be examined to what extent $\mathrm{Cu}, \mathrm{Zn}-\mathrm{SOD}$ contributes to the above-mentioned physiological and pathophysiological conditions as an EDHF synthase.

In summary, the present study provides the novel concept that endothelial $\mathrm{Cu}, \mathrm{Zn}$-SOD plays a pivotal role as an EDHF synthase.

\section{Acknowledgments}

We thank K. Takeshige of Kyushu University Graduate School of Medical Sciences and H. Utsumi of Kyushu University Graduate School of Pharmaceutical Sciences for valuable comments on our work, and I. Kunihiro, M. Motoishi, and Y. Matsuo for excellent technical assistance in this study. This work was supported in part by grants-in-aid (07307010, 10877111, 12877114, and 13670724) from the Japanese Ministry of Education, Science, Sports, and Culture (Tokyo, Japan) and from the Mitsui Life Social Welfare Foundation (Tokyo, Japan).

\footnotetext{
1. Mombouli, J.V., and Vanhoutte, P.M. 1997. Endothelium-derived hyperpolarizing factor(s): updating the unknown. Trends Pharmacol. Sci. 18:252-256.

2. Shimokawa, H. 1999. Primary endothelial dysfunction: atherosclerosis J. Mol. Cell. Cardiol. 31:23-37.

3. Matoba, T., et al. 2000. Hydrogen peroxide is an endothelium-derived hyperpolarizing factor in mice. J. Clin. Invest. 106:1521-1530.
} 
4. Feletou, M., and Vanhoutte, P.M. 1988. Endothelium-dependent hyperpolarization of canine coronary smooth muscle. Br. J. Pharmacol. 93:515-524

5. Chen, G., Suzuki, H., and Weston, A.H. 1988. Acetylcholine releases endothelium-derived hyperpolarizing factor and EDRF from rat blood vessels. Br. J. Pharmacol. 95:1165-1174

6. Rosolowsky, M., and Campbell, W.B. 1993. Role of PGI2 and epoxyeicosatrienoic acids in relaxation of bovine coronary arteries to arachidonic acid. Am. J. Physiol. 264:H327-H335.

7. Fisslthaler, B., et al. 1999. Cytochrome P450 2C is an EDHF synthase in coronary arteries. Nature. 401:493-497.

8. Edwards, G., Dora, K.A., Gardener, M.J., Garland, C.J., and Weston, A.H 1998. $\mathrm{K}+$ is an endothelium-derived hyperpolarizing factor in rat arteries. Nature. 396:269-272.

9. Beny, J.L., and Schaad, O. 2000. An evaluation of potassium ions as endothelium-derived hyperpolarizing factor in porcine coronary arteries. Br. J. Pharmacol. 131:965-973.

10. Taylor, H.J., Chaytor, A.T., Evans, W.H., and Griffith, T.M. 1998. Inhibition of the gap junctional component of endothelium-dependent relaxations in rabbit iliac artery by 18 -alpha glycyrrhetinic acid. Br. J. Pharmacol. 125:1-3.

11. Yamamoto, Y., Fukuta, H., Nakahira, Y., and Suzuki, H. 1998. Blockade by 18beta-glycyrrhetinic acid of intercellular electrical coupling in guinea-pig arterioles. J. Physiol. 511:501-508.

12. Matoba, T., et al. 2002. Hydrogen peroxide is an endothelium-derived hyperpolarizing factor in human mesenteric arteries. Biochem. Biophys. Res. Commun. 290:909-913.

13. Matoba, T., et al. 2003. Electron spin resonance detection of hydrogen peroxide as an endothelium-derived hyperpolarizing factor in porcine coronary microvessels. Arterioscler. Thromb. Vasc. Biol. 23:1224-1230.

14. Miura, H., et al. 2003. Role for hydrogen peroxide in flow-induced dilation of human coronary arterioles. Circ. Res. 92:e31-e40.

15. Yada, T., et al. 2003. Hydrogen peroxide, an endogenous endotheliumderived hyperpolarizing factor, plays an important role in coronary autoregulation in vivo. Circulation. 107:1040-1045.

16. Lacza, Z., et al. 2002. Hydrogen peroxide acts as an EDHF in the piglet pial vasculature in response to bradykinin. Am. J. Physiol. Heart Circ. Physiol. 283:H406-H411.

17. Okado-Matsumoto, A., and Fridovich, I. 2001. Subcellular distribution of superoxide dismutases (SOD) in rat liver: $\mathrm{Cu}, \mathrm{Zn}$-SOD in mitochondria. J. Biol. Chem. 276:38388-38393.

18. Stuehr, D., Pou, S., and Rosen, G.M. 2001. Oxygen reduction by nitricoxide synthases. J. Biol. Chem. 276:14533-14536.

19. Rubanyi, G.M., and Vanhoutte, P.M. 1986. Superoxide anions and hyperoxia inactivate endothelium-derived relaxing factor. Am. J. Physiol. 250:H822-H827.

20. Mugge, A., Elwell, J.H., Peterson, T.E., and Harrison, D.G. 1991. Release of intact endothelium-derived relaxing factor depends on endothelial superoxide dismutase activity. Am. J. Physiol. 260:C219-C225.

21. McIntyre, M., Bohr, D.F., and Dominiczak, A.F. 1999. Endothelial function in hypertension: the role of superoxide anion. Hypertension. 34:539-545.

22. Fukai, T., et al. 2000. Regulation of the vascular extracellular superoxide dismutase by nitric oxide and exercise training. J. Clin. Invest. 105:1631-1639.

23. Didion, S.P., et al. 2002. Increased superoxide and vascular dysfunction in CuZnSOD-deficient mice. Circ. Res. 91:938-944.

24. Beauchamp, C., and Fridovich, I. 1971. Superoxide dismutase: improved assays and an assay applicable to acrylamide gels. Anal. Biochem. 44:276-287.

25. Wheeler, C.R., Salzman, J.A., Elsayed, N.M., Omaye, S.T., and Korte, D.W., Jr. 1990. Automated assays for superoxide dismutase, catalase, glutathione peroxidase, and glutathione reductase activity. Anal. Biochem. 184:193-199.
26. Akaike, T., et al. 1993. Antagonistic action of imidazolineoxyl $\mathrm{N}$-oxides against endothelium-derived relaxing factor/.NO through a radical reac tion. Biochemistry. 32:827-832.

27. Krishna, M.C., Grahame, D.A., Samuni, A., Mitchell, J.B., and Russo, A. 1992. Oxoammonium cation intermediate in the nitroxide-catalyzed dismutation of superoxide. Proc. Natl. Acad. Sci. U. S. A. 89:5537-5541.

28. Headrick, J.P., Gauthier, N.S., Morrison, R., and Matherne, G.P. 2000. Cardioprotection by $\mathrm{K}(\mathrm{ATP})$ channels in wild-type hearts and hearts overexpressing A(1)-adenosine receptors. Am. J. Physiol. Heart Circ. Physi ol. 279:H1690-H1697.

29. Talukder, M.A., et al. 2002. Targeted deletion of adenosine A(3) receptors augments adenosine-induced coronary flow in isolated mouse heart. Am. J. Physiol. Heart Circ. Physiol. 282:H2183-H2189.

30. Shimokawa, H., et al. 1996. The importance of the hyperpolarizing mechanism increases as the vessel size decreases in endothelium-dependent relaxations in rat mesenteric circulation. J. Cardiovasc. Pharmacol. 28:703-711.

31. Inoue, N., Ramasamy, S., Fukai, T., Nerem, R.M., and Harrison, D.G. 1996. Shear stress modulates expression of $\mathrm{Cu} / \mathrm{Zn}$ superoxide dismutase in human aortic endothelial cells. Circ. Res. 79:32-37.

32. Takamura, Y., et al. 1999. Important role of endothelium-derived hyperpolarizing factor in shear stress-induced endothelium-dependent relaxations in the rat mesenteric artery. J. Cardiovasc. Pharmacol. 34:381-387.

33. Yoshida, T., Maulik, N., Engelman, R.M., Ho, Y.S., and Das, D.K. 2000 Targeted disruption of the mouse Sod I gene makes the hearts vulnerable to ischemic reperfusion injury. Circ. Res. 86:264-269.

34. Kawase, M., et al. 1999. Exacerbation of delayed cell injury after transient global ischemia in mutant mice with CuZn superoxide dismutase deficiency. Stroke. 30:1962-1968.

35. Rubanyi, G.M., and Vanhoutte, P.M. 1986. Oxygen-derived free radicals, endothelium, and responsiveness of vascular smooth muscle. Am. J. Physiol. 250:H815-H821.

36. Beny, J.L., and von der Weid, P.Y. 1991. Hydrogen peroxide: an endogenous smooth muscle cell hyperpolarizing factor. Biochem. Biophys. Res. Commun. 176:378-384.

37. Landmesser, U., et al. 2003. Oxidation of tetrahydrobiopterin leads to uncoupling of endothelial cell nitric oxide synthase in hypertension. J. Clin. Invest. 111:1201-1209. doi:10.1172/JCI200314172.

38. Krishna, M.C., et al. 1996. Do nitroxide antioxidants act as scavengers of O2-. or as SOD mimics? J. Biol. Chem. 271:26026-26031.

39. Urakami-Harasawa, L., Shimokawa, H., Nakashima, M., Egashira, K., and Takeshita, A. 1997. Importance of endothelium-derived hyperpolarizing factor in human arteries. J. Clin. Invest. 100:2793-2799.

40. Inokuchi, K., et al. 2003. Role of endothelium-derived hyperpolarizing factor in human forearm circulation. Hypertension. 42:919-924.

41. Uchimura, K., et al. 1999. Changes in superoxide dismutase activities and concentrations and myeloperoxidase activities in leukocytes from patients with diabetes mellitus. J. Diabetes Complications. 13:264-270.

42. Noor, R., Mittal, S., and Iqbal, J. 2002. Superoxide dismutaseapplications and relevance to human diseases. Med. Sci. Monit. 8:RA210-RA215.

43. Wu, R., Millette, E., Wu, L., and de Champlain, J. 2001. Enhanced superoxide anion formation in vascular tissues from spontaneously hypertensive and desoxycorticosterone acetate-salt hypertensive rats. J. Hypertens. 19:741-748.

44. Druzhyna, N., Nair, R.G., LeDoux, S.P., and Wilson, G.L. 1998. Defective repair of oxidative damage in mitochondrial DNA in Down's syndrome. Mutat. Res. 409:81-89.

45. Matzuk, M.M., Dionne, L., Guo, Q., Kumar, T.R., and Lebovitz, R.M. 1998. Ovarian function in superoxide dismutase 1 and 2 knockout mice. Endocrinology. 139:4008-4011.

46. McFadden, S.L., Ding, D., Reaume, A.G., Flood, D.G., and Salvi, R.J. 1999. Age-related cochlear hair cell loss is enhanced in mice lacking copper/zinc superoxide dismutase. Neurobiol. Aging. 20:1-8. 